\title{
The Prospects of International Relations Theories in the 21st Century: From Single Theory to Theoretical Pluralism*
}

\author{
Issaka Sayi Abdul Hamid \\ Brock University, Ontario, Canada
}

\begin{abstract}
Examined in this paper is the theoretical development in the international relations literature with emphasis on theoretical pluralism. The International Relations (IR) discipline is undergoing theoretical pluralism in the $21 \mathrm{st}$ century in explaining global political forces. These theoretical expansiveness is important in moving IR forward in the context of ontological and epistemological orientations. Within the international relations subfield, periods of change have largely been understood through the prism of the great debates. The paper, therefore, contends that theoretical diversity and pluralism has contributed significantly in this contemporary era in explaining global political forces, events and processes.
\end{abstract}

Keywords: theoretical pluralism, ontological, epistemological, great debates

\section{Introduction}

This paper examines the theoretical development in International Relations (IR) literature. It specifically analyzes theoretical pluralism in the discipline and how it has contributed to the success of the discipline. The central argument of this paper is that theoretical diversity and pluralism has enhanced the reputation of IR as an intellectual, academic discipline in explaining global political forces in the 21st century. Researchers and IR scholars have used expansive theoretical underpinnings in recent decades to explain various political events and processes in different political jurisdictions across the globe. Almost all academic disciplines undergo periods of stasis and change for which IR is no exception. Within the international relations subfield, periods of change have largely been understood through the prism of the great debates. It is clear that the perception of the debates and the proliferation of theories continue to shape the field in important ways (Dunne et al., 2013). Various theories, approaches, and paradigms emerge in the discipline due to the ontological and epistemological philosophical perspectives of the various scholars within the discipline. Ontologically, scholars of IR will want to understand what the world consists of (whether it basically consists of sovereign states or individuals with rights, agents and obligations to the rest of humanity). Epistemologically, they will want to know about what human beings can and cannot know about the social and political world. As a result, they asked the question of whether the unit of the political phenomenon should be studied by using empirical data, historical evidence or theoretical paradigms to understand systemic forces that make all states behave the way they do (Dunne et al., 2013). Thus, theoretical diversity and pluralism should be tolerated and allowed to

\footnotetext{
* This paper was presented at the 47th Annual meeting of Northeastern Political Science Association, Philadelphia, November 12-14, 2015.

Issaka Sayi Abdul Hamid, M.A, Department of Political Science, Brock University.
} 
proliferate since a single theory will find it difficult to explain all the political forces and events in IR in the 21 st century. In the light of this, theoretical pluralism has greatly contributed to the development of IR as an academic discipline that explains global political forces in the 21 st century. For the sake of this discussion, the theoretical pluralism refers to the deeper alignment at the epistemological and ontological level though the articulation of various theories.

The study of IR began as a theoretical discipline. Among the foundational texts in the field were the two works of E. H. Carr, The Twenty Years Crisis (first published in 1939) and Hans Morgenthau's work, Politics Among Nations. Carr's and Morgenthau's works set the foundations for international relations theorizing (Carr, 1945; Morgenthau, 1985). Each of the scholars developed a broad framework of analysis, which distilled the essence of international politics from disparate events. Carr and Morgenthau sought to provide the future analyst with theoretical tools for understanding general patterns underlying seemingly episodes; and each reflected on the forms of political actions which were most appropriate in a realm in which the struggle for power was pre-eminent (Carr, 1945; Morgenthau, 1985). Both thinkers sought to explain the nature of international politics in the context of power struggle and the pursuit of self-interest which necessitated the promotion of peace in global politics.

Another genre of scholars also emanated from the discipline with novelideas about IR: Keneth Waltz, John Ruggie, Hedley Bull, David Lake, Alexander Wendt, John Hobson, Paul Warpner, Tim Bartley among others were no exception as far as theorizing is concerned with the discipline (Brown, 2013). Thus, realism, neorealism, liberalism, constructivism, post-modernist, feminism, globalization and new global governance emerge as the dominant and competing paradigms in IR.

This paper, therefore, proceeds, by examining the recent articles of the European Journal of International Relations in assessing the state of IR as an academic and intellectual discipline. Specifically, it evaluates the merits of arguments put forward by Dunne, Hanson and Wight's End of International Relations Theory; Brown's Poverty of Grand Theory and William's In the Beginning: The International Relations Enlightens and the End of International Relations Theory (William, 2013). These articles are part of the 2013 European Journal of International Relations (EJIR). The articles are of special interest and importance of their discussion of international relations theories. They sought to discuss theorizing within the discipline and this paper intends to push the argument a bit further on the state of IR theories.

More importantly, it analyzes the argument being advanced by these scholars with reference to the relevant readings from these journals. The first part of this essay scrutinizes the concept or ideas about theories and theorizing in IR, the second part examines the diversity and theoretical pluralism in the discipline and how it impacted the success of an IR, and the final part provides a conclusion to the paper.

\section{Theories in International Relations}

Dunne et al. (2013) in The End of International Relations Theory argue that in an academic discipline as wide ranging as IR, it is no surprise that the definition, role and function of theory is one of the most highly contested issues (Dunne et al., 2013). The sheer diversity and complexity of what is studied ensures that there will be multiple perspectives on what the most important factors are and how inquiring should proceed (Dunne et al., 2013). Dunne et al. contend that the lack of consensus surrounding a precise definition of theory might form part of the explanation for the current status of theory in IR. The theory still plays a role in almost all the articles of IR published in the journals for the last five years, but it is very much in terms of theory testing as 
opposed to theory development (Dunne et al., 2013, p. 407). The scholars identified explanatory theory, critical theory, and constitutive theory as among the competing theories that scholars within IR use to explain political events. Nonetheless, Waltz (1979) in Theory of International Politics defines theories as the collections or sets of laws pertaining to a particular behavior or phenomenon. Theories explain or predict social and political phenomena. Students of IR use theories to understand the reality in the international community. He asserts that scholars of IR believe that since empirical knowledge is potentially infinite in extent, without some guidance we can know neither what information to gather nor how to put them together so that it becomes comprehensible (Waltz, 1979). If we could directly apprehend the world that interests us, we would have no need for theory (Waltz, 1979). Thus, theories provide us with guidance on how to gather information and apprehend the world in an empirical manner.

Some scholars are of the view that theories are the edifice of truth, which they will build inductively. They define theories as the hypothesis that are confined and connected (Waltz, 1979). Theories cannot be constructed through induction alone, for theoretical notion can only be invented not discovered. A theoretical notion, according to Waltz (1979) may be accepted as a force or an assumption (Waltz, 1979). It does not explain or predicts anything and are neither true nor false. Theoretical notion finds their justification in the success of theory that employs them (Waltz, 1979). A theory though is related to the world about which explanations are wanted; always remain distinct from that world. "Reality" will be congruent neither with a theory nor with a model that may represent it (Waltz, 1979). With regards to this, political scientists think that the best model is the one that reflects reality most accurately. Model is used in two principal ways: In one sense, it represents theory and in another sense it pictures reality while simplifying it (Waltz, 1979). Thus, a model of theory will be about as removed from reality as the theory it represents. Theories can be tested by experience, but there is no way from experience to the setting up of theory. Waltz (1979) notes that it is possible to arrive at a theory inductively is to claim that we can understand the phenomena before the means for their explanations are contrived. Theories do construct a reality, but one can never say it is the reality (Waltz, 1979). Facts do not determine theories; more than one theory may fit any set of facts. Theories do not explain facts conclusively. We can never be sure that a good theory will not be replaced by a better one (Waltz, 1979). In the same vain, Dunne et al. (2013) posit that the best kind of theory helps us to see the world in particular kinds of ways and hence constructs the world we see, but we should take care to avoid the kind of dogmatism that leads us to believe our theory is immune from revision when it intersects with that world (Dunne et al., 2013). To them, in order for IR to fulfill its promise as a discipline, we have to bring theory and the world together: to use the world as a raw material of theory; and to use theory to help us formulate our study and to help us explain, understand and potentially change the varied practices of IR. The broader the range of IR theory we study, the broader will be our conception of theory (Dunne et al., 2013).

Further, Waltz (1979) opines that theories are not the occurrences seen and the associations recorded, but it is instead the explanation of them. Though it is believed that truth is won and explanation achieved through the accumulation of more and more data and the examination of more and more cases. If more and more data is gathered and associations established, however, we will not finally know that we know something; rather we will end up having more and more data and a large set of correlations (Waltz, 1979). Data do not speak for themselves; observation and experience never lead directly to knowledge of causes. Therefore, theories are important and without them there can be no research. There can be no specification of the object under study (ontology) or standards of evidence on which claims about the world might be judged (epistemology) (Dunne et 
al., 2013). In this sense, IR scholars theorize in the attempt to explain our experiences of the world in terms of something which may not have been experienced and which may not even be a possible object of experience. Through this, the scholars of IR are able to tell us something about the world (Dunne et al., 2013).

Following the ontological and epistemological configurations, various theories have sprung up within the discipline of IR in an attempt to explain a social and political phenomenon. For instance, why will realists focus on specific images that highlight states, geopolitics, and war while remaining blind to another phenomenon such as class divisions, order, material inequalities and norms (Morgenthau, 1985). Through the study of theory, scholars are able to examine the various philosophical configurations and how distorted and distorting any political worldview may be. In the theory of IR, it is important to be concerned with how we approach the study of world politics as we are with events, issues and actors in the global system. It is necessary to examine background assumptions because all forms of social analysis raise important questions about the microcosm of the observer. Debates about the object of analysis have been especially important in the discipline with emphasis on the structure agency relationship.

Waltz (1979) provided a good example of theorizing about the state which departs from Hans Morgenthau's classical realism (Hans Morgenthau, 1985). Classical realism originally explained the machinations of international politics as being based in human nature and, therefore, subject to the ego and emotions of world leaders. A neorealist thinker like Waltz (1979) instead theorizes that structural constraints will determine behavior in international relations. Neorealist is often called "structural realism", which signifies that the theory primarily centers on the effects of the structure of the international system when it seeks to explain outcomes in international politics. Waltz (1979) theory of structural realism is the bedrock theory of IR. He seeks to explain how states, in particular, the most powerful ones behave, how they interact with each other on the international arena. He endeavors to construct a very general framework for explaining recurring patterns of state behavior and state interaction in the international system. Structural realism attempts to abstract from every attribute of states except their capabilities in order to highlights the impact of anarchy and the distribution of capabilities (Waltz, 1979). To Waltz (2011), international structure emerges from the interaction of states and then constrains them from taking certain actions while propelling them towards others. Therefore, despite great variations in the attributes and interactions of states, there is a striking sameness in the quality of international life through the millennia (Waltz, 1979).

In Waltz's "conception of structure", two things are especially noteworthy about the international systems. First, the international systems ordering principle is anarchy. This means that there is no such thing as a world government; there is no higher authority above the main units that exists in the system (states). This, therefore, results in an international system that is essentially a self-help system consisting of states that are autonomous, functionally undifferentiated actors each of which must always be prepared to fend for itself. The units of the system closely resemble each other with regard to the functions they perform, the tasks they face, the primary goals they seek, and how they go about accomplishing their objectives. The main point is that, under anarchy, each and every state by and large operates on its own without having recourse to any higher authority (Waltz, 1979).

The second defining principle of the structure of international politics according to Waltz (1979) is the distribution of capabilities across the units inhabiting the international systems. Capabilities or power, vary significantly between states; states, through functionally undifferentiated, are differentiated according to how much power they possess. Variations in power yield variations in the types and magnitude of structural 
constraints that states face, thereby effectuating variation how states behave or should behave (Waltz, 1979). The central conclusion of structural realism is that anarchic state "balance" rather than a bandwagon. In hierarchical political orders, actors tend to jump on the bandwagon of a leading candidate or recent victor, because losing does not place their security in jeopardy (Waltz, 1979). Bandwagons attempt to increase their gains by siding with a stronger party. In anarchy, however, bandwagoning counts disaster by strengthening someone who later may turn on you. The relativity of power requires states to be more concerned with relative strength than with absolute advantage (Waltz, 1979). Bandwagoning seeks absolute gains, aligning early with a rising power to gain a share of the profits of victory.

Ruggie (1986) theorizes on the contrary that, in any social system, structural change itself ultimately has no source other than unit-level processes. His point is to research beyond the confines of conventional realist-analysis without violating its basic premise. An important limit of Waltz's theory according to Ruggie (1986) comes from an appropriate definition of the second level of structure: differentiation between the units, and particularly from the idea that this level should be dropped as a factor of change of the international structures. Further, Ruggie (1986) takes issue with Waltz's model on two main points: Waltz fails to recognize both dimension and determinant of change in world politics. Ruggie (1986) argues that a dimension of change is missing from Waltz's model because he drops out the second analytical components of the political structure, the differentiation of units (that is, the structure of the state) when theorizing about the international system. Waltz interprets differentiation as differences among units rather than as the separation of units. Ruggie (1986) claims that if one's focus on the principles that separate units from one another, the second component of structure does not drop out and becomes a crucial source of structural variation.

Further, Ruggie (1986) posits that without taking the second image into account, with its shift from feudalism to the modern principle of sovereignty to organize states, one cannot account for the most important central change in international politics in this millennium. Ruggie (1986) then enumerates for specific consequences for waltz's model if the second component is regarded as a dimension of transformation in the international system. Waltz's deduces from anarchy certain constraints on state action, Ruggie (1986) believes these constraints arise from the principles that separate the units. It is useful to compare the object of analysis and scope of inquiries of Waltz, Ruggie and that of Bull.

Bull (1997), a liberalist in The Anarchical Society analyzes the extent to which anarchy is compatible with the world order in international politics. He scrutinizes anarchy by distinguishing between a system of state where states are in regular contact with one another and the interaction between them makes the behavior of each necessary in the calculation of that of others, and a society of state where a group of states, conscious of certain common interests and common values, form a society in the sense that they conceive themselves to be bounded by common set of rules in their relations with one another (Bull, 1977). To him, international order is a pattern of international activities that sustain the primary goals of states such as preservation of the system; maintaining the sovereignty of individual states' peace and social life (Bull, 1977, pp. 16-19).

Bull (1977) presumes that there is a sense of common interest in achieving the elementary goals of social life. Rules help to define the type of behavior that is consistent with the goals. Order in society is maintained not merely by a sense of common interests in creating order or avoiding disorder, but also they are rules that spell out the kind of behavior that is orderly (Bull, 1977). These rules may have the status of law, of a morality of customs or etiquette or simply the operations of procedures. He contends that when rules are not merely constructed but socially effective, it is because institutions (defined as habits and practices, shaped towards the 
realization of common goals) exist, which ensure that rules are made, communicated, administered, interpreted, enforced, legitimized, adaptable, and protected against potentially threatening social developments. Within the modern state, the institution of governments accomplishes all these functions (Bull, 1977).

Bull (1977) launches into an anthropological assessment of the sources of order in "primitive stateless societies". He posits that these societies exhibit order in the sense that conduct conforms to elementary goals (life, truth, and property) of social coexistence. Those functions normally performed by the government are instead carried out by lineage and locality groups. Conformity of rules is brought about by "conditioning and inertia" such as moral sanctions like public ridicule and rivals. "Self-help" mechanisms like retaliation arise where such sanctions cannot induce conformity (Bull, 1977). Bull (1977) relates the condition of primitive societies to international society. To him, the maintenance of order in the international society takes place in both the absence of government and solidarity. For Bull (1977), order in the international society is maintained through common interests (states have the sense of common interest in the elementary goals of social life, even if these objectives differ), rules (fundamental and constitutional normative principles of world politics that identifies the idea of society of states) and institutions (sovereign states are deemed as chiefly responsible for performing the functions of helping to make rules effective in the absence of government).

States collaborate with institutions of the international society, which include the balance of power, international law, the diplomatic mechanisms, the managerial system of great powers and wars to protect the rules (Bull, 1977). In contrast to Bull's assertions, the neorealist will argue that states do not have a common interest, but competing interests which compel them to be in self-help. The self-help principle is the condition in which states seek their own interests and will not subordinate their interests with others (Waltz, 1979). They also reject the notion that there are rules and institutions outside the state that govern the conduct of sovereign states in the international society. They view the state to be independent and always want to maximize its interest. Moreover, to neo-realist there is nothing like order in the international anarchical system in which states find themselves.

In assessing international law, Bull (1977) contends that the existence of international law shapes international behavior and international order. $\mathrm{He}$ is of the view that the efficacy of international law in international society depends on measures of self-help. In the absence of a central authority with preponderant power, rules of international law are upheld by measurements of self-help, including threat, and the use of force by individual states (Bull, 1977). Thus, to Bull (1977), within the international society there are rules generally believed to have the status of law, requiring states and other actors to do or refrain from doing certain things. Albeit, it is impossible in the international society to find rules of recognition; rules of change and rules of adjudication (Bull, 1977). He asserts that states obey international law in part because of the habit of inertia; thereby are programmed to operate within a framework of established principles (Bull, 1977). These principles are that states obey international law because of the value attached to it as a result of coercion or based on the interest of the state (Bull, 1977).The international law does not rest on the willingness of states to abide by these principles to the detriment of their interests, but they do so in the interest to conform to it (Bull, 1977, p. 140).In relation to the international order, Bull (1977) posits that international law has been identified as a supreme normative principle of the political organization of mankind. Secondly, the function of international law has been to state the basic rules of coexistence among states and other actors in the international society. Finally, international law is to help mobilize compliance with the rules of international society (Bull, 1977). However, he argues that the international law is not a necessary condition for international order, it is not 
sufficient to bring about order, a particular interpretation of international law is sometimes found actually to hinder measures to maintain international order (Bull, 1977). He contends that the status of the subject of international law is not only related to states but also other authorities such as the United Nations, regional integration and multinational corporations (Bull, 1977).

In contrast to Bull's argument, realists and neo-realists reject the notion of international law in the international society. To them, states are not subjected to any other law apart from the laws that exist within their independent states. That is, the international system has no laws meant to govern the behavior of states. Due to the anarchical nature of the international system, states try to achieve their goals through internal balancing.

Another non-classical theory that has gained a central attention within IR is the constructivist theory. Alexander Wendt (1992) in Anarchy is what States Make of It developed a constructivist argument, drawn from structuration and symbolic interaction sociology on behalf of the liberal claim that international institutions can transform state identities and interests (Wendt, 1992). He puts forth a constructivist argument-share a cognitive inter-subjective conception of a process in which identities and interests are endogenous to interaction, rather than a rationalist-behavioral in which they are exogenous - rejecting the realist belief that structure of the international systems-anarchy of self-help forces states to play competitive power politics (p. 394). Again, Hobson (2000) asserts that constructivists are of the view that identities of states are constructed through norms, which in turn define states interests. As norms construct identities, so interest subsequently changes, leading to changes in state policy. Thus, interests and identities are informed by norms which guide actors (states) along certain socially prescribed channels of appropriate behavior (Hobson, 2000). To him, unlike rationalist, constructivists assert that norms do not simply regulate. For constructivists, international society is primarily a normative structure comprising of autonomous and constitutive norms, which exists independent of the state. In addition, Hobson explores the variants of constructivism that are related to the international relation. He identifies international society centric constructivism (theory of low domestic agential power of state and high international agential state power), state-centric constructivism (theory of the low-moderate domestic agential power of state and moderate or high international agential state power) and radical constructivism or postmodernism (theory of very low domestic agential state power of the state but moderate international state power) (Hobson, 2000) as the main variants of constructivism.

Martha Finnemore (1996), also a constructivist, in her book National Interests in International Society, proposes another variant of constructivism, systemic analysis. Her starting point is that definition of states is on norms of international society and the way in which they affect states identities and interest (Finnemore, 1996). State interest is defined by identities and interests. But instead of looking at the social interaction between states, her focus is on the norms of international society and the way in which they affect state identities and interests. To her, state behavior is defined by identity and interest. Identity and interest are defined by international forces shaped by the norms of behavior embedded in international society. The norms of international society are transmitted to states through international organizations (IOs). They shape national policies by teaching states what their interests should be (Finnemore, 1996, pp.1-2). Finnmore's analysis contains structure-agent approaches vis-à-vis capabilities and preferences. She argues that socially constructed rules, principles, norms of behavior and shared beliefs may provide states, individuals, and other actors with understandings of what is important as valuable and effective. To Finnemore (1996), preferences are strongly influenced and often 
constituted by social norms, culturally determined roles and rules and historically contingent discourse. That notwithstanding, she emphasizes the importance of intersubjective understanding in structuring the ways in which actors understand what kind of actions are valuable, appropriate and necessary (Finnemore, 1996). She makes an erudite fascinating argument that constructivism does not oppose realism or liberalism, stating that the relationship is complementary, not competing, since norms shape interest (Finnemore, 1996). Norms and values shape what states do with their power and wealth according to Finnmore (1996). She defines these norms as shared expectations about appropriate behavior held by a community of actors (Finnemore, 1996). Therefore, both the method of constructivism as well as the content that is brought to bear on norms are neutral and can be filled by any set of values or any agenda.

It is also useful to discuss the Feminist theory which has emanated within the discipline of IR in recent times. Feminist theory has a different approach from the above theories discussed. Feminist scholars use different ontological and epistemological perspective when they engage in theorizing in international relations. They challenge the ontological and epistemological presuppositions of IR with claims of gender bias (Tickner, 1997). Feminist theory since it entered the field of IR in the late 1980's, has often, but exclusively, been located within the critical voices of the "third debate" (Tickner, 1997). Feminist theorists believe that since the world is characterized by gender hierarchies that are detrimental to women, they would be unlikely to take such an epistemological stance. Feminist are arguing for moving beyond knowledge frameworks that construct international theory without attention to gender and for searching deeper to find ways in which genders hierarchies serve to reinforce socially constructed institutions and practices that perspective difference and unequal role expectations, that have contributed to fundamental inequalities between women and men in the world of international politics (Tickner, 1997).

The feminist theorist is concerned with social relations, particularly the investigation of causes and consequences of unequal relations between women and men, the questions they ask about IR are likely to be quite different from those of international theorists primarily concerned with the international action of states in the international systems (Tickner, 1997). Feminists are often skeptical of empiricist methodologies that claim neutrality of facts. Many feminists see structural regularities such as gender and patriarchy, which they define as socially constructed and variable across time, place and culture rather than as universally natural (Tickner, 1997). In constructing feminist theory, feminists draw on a variety of philosophical traditions and literature outside international relations within which most IR are trained (Tickner, 1997).

Although the above theories by realist, neorealist, liberalist, constructivist and feminist may share some basic assumptions, the exponents of these theories have widely differing and even conflicting positions on theorizing in international relations. As noted earlier, in the theory of international relations, it is important to be concerned with how theorists approach the study of world politics as we are with events, issues and actors in the global system. Thus, the works of these classical and modern theorists in IR could be viewed in the context of theory (prepositions that seek to explain or predict social or political phenomenon), critical theory (builds analysis on the basis of an examination of the causal factors that brought about a particular states of affairs) and constitutive theory (for these theorists, the social world is constituted through the ideas, or theories that we hold) (Dunne et al., 2013). Consequently, as indicated earlier, this theoretical diversity and proliferation within the discipline of IR is tolerated because each theory has an important and significant component of explaining global political forces. 


\section{Theoretical Pluralism}

Brown's (2013) article, "The Power of Ground Theory" makes an interesting and significant contribution to the literature of IR concerning the progress of the discipline as a result of the emerging theories within IR in the last 30 years. To him, both liberalism and realism are still important theories within the discipline and have great dealings to say about how the world works. He observes that the world would have been a better place over the last decades or so if more notice has been taken of what they say. Brown (2013) opines that there is the need for a critical problem-solving theory that relates directly to the real world. He is of the view that in the last decades there has been a tremendous publication on IR theories and that if there is any crisis at all in the discipline, scholars of IR have refused to engage in real world issues.

Scholars of IR theories have a lot to offer to the wide world of learning, and there is no reason to be unduly depressed by the fact that this does not include many theoretical innovations that will be picked up by other social sciences (Brown, 2013). Nonetheless, Brown asserts that despite the debacles about the best theories within the discipline, there has been a tremendous progress with the theoretical development in the discipline (Brown, 2013).

In fact, it is important to recognize the significance of realism and liberalism in understanding the social and political world, even though this paper is of the view that these two theories alone cannot offer adequate explanations to the empirical world. It is, therefore, important for scholars of IR to move away from theoretical contestations and inter-paradigm debates which have the tendency to stagnate the level of developments in the discipline. Lake (2011) opines that we do not produce understanding through contestations at either theoretical or epistemological levels. Rather, understanding the real world is achieved by asking questions about important phenomena that we do not understand well through employing of appropriate theories (Lake, 2011). As a result of theontological and epistemological differences, it is desirable to allow individual scholars to theorize about how they best understand the social and political world so that they can best add up to the stock of human knowledge and provide some insight on how to improve social life. More importantly, Lake (2011) notes that "today, no single theoretical or epistemological approach deserves hegemony".

The diversity of theory and method is necessary, at least at this stage of our intellectual development. Intellectual monocultures are rightfully feared, but the current cacophony is not what we should aspire to (Lake, 2011). Lake (2011) notes that "Rather than useful debate, we have turned inward to self-contained research traditions and epistemologies and, in turn, we focus on first principles". Intellectual progress does not come from proclaiming ever more loudly the superiority of one's approach to audiences who have stopped listening (Lake, 2011). Lake (2011) opines that as students of international relations it is important to end the theoretical crusades and seek progress in understanding real problems of world politics. Perhaps then we will earn the privileges society has accorded us. This argument of Lake is very insightful as far as the proliferation of theories and diversity is a concern in IR due to ontological and epistemological perspectives.

The manifestation of globalization in the last decades within the global politics cannot be overemphasized. The undermining of states sovereignty is seen as one of the most significant aspects of globalization (Marchand \& Runyan, 2000). Several actors apart from the state have also emerged in global politics, performing some functions of the state. Scholars of IR have pointed out that, the reduced role of the state in economic matters raises serious questions about the state of theorizing within the discipline (Marchand \& Runyan, 2000). Issues about trade have taken a center stage in the global politics. The international political world has undergone a 
major transformation over past generation (Ruggie, 2004).

The phenomenon of globalization has led to the increase in transnational, regional, and global networks or institutions of regulations and governance, which has also grown considerably in terms of influence and power. Apart from government and government officials, private organizations and citizens have gained a worldwide presence as they mobilize and organize across political borders to advance and achieve their shared objectives and interests (Kollman, 2008). The intensification of globalization over the last decades has been recognized within Westphalia system. Globalization challenges the one-dimensional orthodox descriptions of world politics that regards it entirely in terms of the power struggle between the states and geopolitics.

Under the forces of globalization, states are progressively finding themselves entrenched overlapping and condensing worldwide networks of multilateral organizations and multilateral politics, transnational networks and associations and worldwide policy networks of official, non-governmental and corporate actors (Ruggie, 2004). Globalization has given rise to a global governance complex, which embraces states, transnational agencies and networks and international institutions (Ruggie, 2004). The function of this governance complex begins to intervene in, regulate or promote the shared interests and concerns of humanity, and has led to the rise in power and influence of non- governmental organizations (NGOs) and international institutions in the making and implementation of global politics (Ruggie, 2004; Kollman, 2008).

Realists have acknowledged the fact that states are the principal actors in the international system and that the international system itself is in a state of anarchy. It is important to contend that as NGOs and international institutions have grown in power and influence in the international systems, states had to recognize them as legitimate and important actors in the international system (Morgenthau,1985). Further, with the establishment of international institutions such as the United Nations (UN), European Union (EU), North Atlantic Treaty Organization (NATO), African Union (AU), the realist claim that the international system is in a state of anarchy because its lack of central authority figures no longer holds, as the institutions maintained above are all geared towards international and regional governance.

Some scholars also argue that the global governance complex and the rise of inter and intra-national institutions and organizations have eroded and diminished the authority of sovereign states, as these characteristics which were attached to the state under the Westphalian systems are being diffused both upwards to international institutions (Borzel \& Risse, 2010). As mentioned above, globalization has given rise to the emergence of global governance system (With this system operating alongside states are international institutions, and transnational agencies) (Borzel \& Risse, 2010). With reference to the EU, it is obvious that states are no longer pursuing their security objectives individually but are entering into security communities with other states, which has as one of its objectives the collective security of all its members. This is a step away from the realist claims of self-help as the issue of anarchy in the international systems has been resolved by the establishment of international institutions that have rules and regulations to which states must adhere in order to enjoy membership (Waltz, 1979).

Furthermore, with security being a collective interest of the institutions, states no longer have to go at it alone as the members of a security community are not left in a state of uncertainty about the objectives of their neighbors but rather are reassured by their common security objectives. Cooperation among states is also facilitated by international institutions, transnational agencies and non-governmental organizations as states cooperate with one another on multitude levels and concerning various issues through these non-state actors. 
With reference to the above argument, though realism is an important theory in global governance, some of its monumental assumptions are weakened due to the emergence of globalization (Ruggie, 2004; Borzel \& Risse, 2010). Against this backdrop, the pursuit of theoretical proliferation is tenable and that theoretical eclectism is likely to be more productive for the success of IR.

Consequently, with regard to the liberal approach to theorizing international relations, part of liberalism assumptions is the recognition of non-state actors such as international institutions, multinational corporations, and NGOs being important and dominant actors in international relations. Liberalists theorize a considerable amount of influence when setting the political agenda on the international stage. In an increasingly interdependent global economy, Multinational Corporations (MNCs) have also come to play a vital role in international relations and in some cases shaping political events in host states (Ruggie, 2004; Borzel \& Risse, 2010). Liberals argue that the universal condition of world politics is globalization. States are and always have been embedded in a domestic and transnational society, which creates incentives for economic, social and cultural interaction across borders. The great emphasis on non-state actors as well as transnational, socioeconomic factors has helped to explain the emergence of globalization.

Liberal theory has contributed significantly in explaining the dilemma of global governance. Nonetheless, it is worthy to note that it could not explain the entire global governance approach (Borzel \& Risse, 2010, p. 118). A new dimension of global governance has advent due to the attention given to Corporate Social Responsibilities (CSRs). CSR requires firms to integrate environmental and human rights norms into their production, management and general business practices (Borzel \& Risse, 2010). Thus, theoretical approaches used to explain the phenomena of governance will fall short without incorporating the constructivist theory. It has been the argument of this paper that theoretical proliferation has contributed to the success of IR. The constructivist theory has contributed to the most existing literature of IR because of its ability to fit in the modern governance approach. Though both realism and liberalism have produced insightful explanations to IR, I think their explanations is not enough for theorizing in the discipline in this contemporary time. Thus, scholars theorizing within the context of CSR have enriched the discipline through their fruitful contributions to the discipline.

The constructivist theory has been used to explain the role international business norms play in regulating the behavior of firms. Constructivists claim that norms play an important role in international life (Borzel \& Risse, 2010). The insights of the constructivist theory have added a great deal to IRs understanding as to why firms act the way they do and how their behavior is regulated (Kollman, 2008).

Aside the contributions of constructivist theory in IR, feminist theory has also contributed significantly to the literature of international relations as a whole. The feminist theory demonstrates the underlying biases embedded in the key foundations of conventional IR theory. They also provide a rich analytical tool that will continue to make insightful contributions to IR discipline.

In contrast to the changing phenomenon of global politics, I would argue that theoretical monism or "monotheism" would rather depreciate the quality and intellectual scholarship in the IR discipline. No single theory can capture all the complexity that exists in the global politics. IR as a discipline is better off with diverse arrays of competing theories rather than a single theoretical underpinning. Take, for example, the analytical implication of the Arab spring in 2011. There is the need for a completely new kind of theories and approaches to better explain the growing paradigm shift in the Middle East politics, or better still refining or reshaping the old existing classical theories. With this IR can be useful in explaining a certain current 
phenomenon in global politics and also provide a scientific observation and theoretical progression. That is not to say that the classical theories are obsolete or anachronistic, archaic or old fashion. But to put forth arguments about the importance of competition between the IR diuretic that would help identify pros and drawbacks within the IR discipline.

There is no need for us to stick to one theory, there is the need to identify what has actually changed in the global politics, including new issues of global terrorism, balance of power, China-Africa relations, China and the rest of the world, emerging issues about culture, identity, responsibility to protect and America's foreign policy towards the Arab world. These and many other important issues demand attention from the scholarlistic point of view to do justice to these emerging issues. Though IR scholars have been debating and vindicating the fact that he disciplines is yearning for new kinds of theories in a quest for the new beginning of the new global politics. For example, considering the new war on global terrorism and the position of China, Russia, US and the west, one would think that this would be an interesting area for scholars of IR to theorize for the major and transformational development on theses global issues.

Theoretical monism has fissiparous tendencies to undermine efforts to better explain key features of new global politics within the IR discipline. IR theories should not be viewed as a "sweater, but a skin" that we can do way theories in the field of IR. Even in recent times, the field of political Science has widened its gamut to celebrate the diversity and the heterogeneity in its theories. This is because the field is not depicted as a smaller club rather as a bigger church of like-minded persons (March \& Stocker, 2010). Thus, IR as a discipline is enriched by the variety of theories and approaches that are adopted in the discipline.

\section{Conclusions}

This paper argues that theoretical pluralism is healthy in IR and it has contributed to the success and development of the discipline in the 21 st century. Due to ontological and epistemological differences it is prudent to allow the growth of diverse theories within the discipline otherwise the discipline will stagnate. The failure to allow more competing theories within IR could lead to the withering away of the discipline since the classical theories alone will find it challenging to explain the gradual changing of global politics. Today fresh concepts such as human right, global governance among others, are emerging and it is very significant for IR scholars to come out with fresh theories to explain the emerging global phenomena. Realism, neorealism, liberalism, constructivism, and feminism have contributed immensely and have provided insightful tools in analyzing and scrutinizing politics in the global perspectives. Thus, theoretical diversity is a necessary component in the growth of knowledge. It is found in this paper that it is untenable to use a single theory to explain social and political events within IR. As a result, we have to embrace the proliferations of theories in order to make empirical analysis within the discipline of international relations.

\section{References}

Borzel, T. A., \& Risse, T. (2010). Governance without state: Can it work? Regulation \& Governance, 4, 113-134.

Brown, C. (2013). The poverty of grand theory. European Journal of International Relations, 19(3), 483-497.

Bull, H. (1977). The anarchical society. A study of order in world politics. Basingstoke, London.

Carr, E. H. (1945). Twenty years' crisis, 1919-1939: An introduction to the study of international relations. Macmillan.

Dunne, T., Hansen, L., \& Wight, C. (2013). The end of international relations theory? European Journal of International Relations, 19(3), 405-497.

Finnemore, M. (1996). National interests in international society. Ithaca: Cornell U. Press.

Hobson, J. M. (2000). “Constructivism” in Hobson, the state and international relations. Cambridge U. Press. 
Kollman, K. (2008). The regulatory power of business norms: A call for a new research agenda. International Studies Review, 10, 397-419.

Lake, D. (2011). Why "isms" are evil: Theory, epistemology, and academic sects as impediments to understanding and progress. International Studies Quarterly, 55, 465-480.

March, D., \& Stoker, G. (2010). Theory and methods in political science (2nd ed.). Pelgrave Macmillan, New York.

Marchand, M., \& Runyan, A. (2000). Introduction: Feminist sights of global restructuring. In A. Marchand \& A. S. Runyan (Eds.), Gender and global restructuring (pp. 1-22). London: Routledge.

Morgenthau, H. (1985). Politics among nations: The struggle for power and peace. New York.

Ruggie, G. J. (1986). Continuity and transformation in the world polity. In R. Keohane (Ed.), Neo-realism and its critics (pp.131-157). New York: Columbia University Press.

Ruggie, G. J. (2004). Reconstituting the global public domain-issues, actors, and practices. European Journal of International Relations, 10(4), 499-531.

Tickner,A. J. (1977). You just don’t understand. International Studies Quarterly, 41(4), 611-632.

Waltz, K. N. (1979). Theory of international politics. New York: Random House.

Wendt, A.(1992). Anarchy is what states make of it: The social construction of power politics. International organization.

Williams, M. C. (2013). In the beginning: The international relations enlightenments and the ends of international relations theory. European Journal of International Relations, 19(3), 647-497. 